\title{
The importance of human-macaque folklore for conservation in Lore Lindu National Park, Sulawesi, Indonesia
}

\author{
ERIN P. RILEY
}

\begin{abstract}
The emerging field of ethnoprimatology focuses on the conservation implications of ecological and cultural interconnections between humans and other primates. The ethnoprimatological research reported here examined how the Tonkean macaque Macaca tonkeana is situated in the folklore of villagers in Lore Lindu National Park, Sulawesi, Indonesia. Data were collected using ethnographic interview techniques. The interviews revealed that villagers envision monkeys and humans as biologically, ecologically and culturally interrelated. The perceived cultural linkages between humans and macaques, however, are more salient among the indigenous To Lindu than among migrants. For many To Lindu the folklore has resulted in a taboo that prevents them harming the macaques, despite the species' frequent crop-raiding behaviour. The conservation significance of the taboo is therefore the local protection it affords this endemic primate. This research lends support for the incorporation of informal institutions, such as taboos, in the conservation management of protected areas.
\end{abstract}

Keywords Ethnoprimatology, Indonesia, Macaca tonkeana, primates, protected areas, Sulawesi, taboos, Tonkean macaque

\section{Introduction}

T UCN (2009) estimates that almost half of the world's non-human primates are threatened with extinction, with $29 \%$ categorized as Endangered or Critically Endangered. Ninety percent of all primate species occur in tropical forests, which are being converted to human use faster than any other habitats (Achard et al., 2002). Throughout much of the 2oth century efforts to preserve these tropical forests and their wildlife centred on the Western-based idea of a protected area, in which forms of human intervention, such as settlement and subsistence and commercial uses, are prohibited (West et al., 2006).

Beginning in the 1980 s, the international conservation movement has begun to place less emphasis on the traditional model of human exclusion, recognizing that protected areas need to be managed with the cooperation

ERIN P. RILEY Department of Anthropology, San Diego State University, San Diego, California 92182-6040, USA. E-mail epriley@mail.sdsu.edu

Received 10 March 2009. Revision requested 16 April 2009.

Accepted 29 April 2009. and support of local people (Brandon \& Wells, 1992; Brechin et al., 2003; Wells \& McShane, 2004). Anthropologists and other social scientists have contributed to this movement by identifying local reasons for conservation (Kottak \& Costa, 1993) and by elucidating environmental ideologies and patterns of decision-making that encourage or impede conservation efforts (Orlove \& Brush, 1996; Mascia et al., 2003). The emerging field of ethnoprimatology (Sponsel, 1997) is the contribution of anthropological primatology. Drawing on folk biology (i.e. the way people understand and categorize plants and animals; Medin \& Atran, 1999) and ethnoecology (i.e. people's knowledge, beliefs and values of their environment), ethnoprimatology provides both a theoretical framework and a methodology to address the ecological and cultural interconnections between humans and other primates and the implications these interconnections have for conservation (Fuentes \& Wolfe, 2002).

Investigations of cultural interconnections focus on how humans and other primates are linked via central elements of human culture; e.g. by elucidating how people conceptualize and categorize features of their surrounding environment, such as forests and the wildlife they host, how these conceptualizations may vary across groups of people (Lowe, 2004), and the social and mythological relationships between humans and other primates (e.g. Cormier, 2003). Ethnoprimatology is also concerned with how these conceptualizations and relationships shape people's behaviour towards non-human primates and nature in general. In some environments these cultural elements may hinder primate conservation. For example, in his research with the Matsigenka in Manu National Park, Peru, Shepard (2002) identified how culture contact, changing resource use practices and demography are affecting the way the Matsigenka subsists, changes that are now negatively affecting the area's primates.

Human-non-human primate cultural conceptions can also contribute to primate conservation. For example, Asia is often considered a model for cultural tolerance of wild primates (Chapple, 1993; Knight, 1999). Among Hindus in India and Bali, monkeys have a sacred status and are therefore tolerated and unharmed (Wheatley \& Harya Putra, 1995). Because Buddha was a monkey in one of his reincarnations, Buddhism has been credited with promoting tolerance and conservation of macaques in China (Zhao, 2005) and Thailand (Eudey, 1994). 
Here, I present ethnoprimatological research that investigated the cultural interconnections between humans and Tonkean macaques Macaca tonkeana in Lore Lindu National Park, Sulawesi, Indonesia. Specifically, I examine how the Tonkean macaque is conceptualized by local villagers, how these conceptualizations shape villagers' behaviour towards the macaques, and the implications people's perceptions and behaviour have for conservation in a UNESCO-recognized protected area.

\section{Study area}

The research was conducted in the Lindu highland plain in Lore Lindu National Park, Central Sulawesi, Indonesia (Fig. 1). This $2,180 \mathrm{~km}^{2}$ Park is designated a UNESCO Man and the Biosphere Reserve (TNC, 2001). The Park provides watershed protection for two major river catchment systems and habitat for many of Sulawesi's endemic birds and mammals (Lee et al., 2007), including one of the seven endemic macaques, M. tonkeana, categorized as Vulnerable on the IUCN Red List (IUCN, 2009).

As an enclave within the Park, the Lindu plain is considered a Special Status Area in which small-scale forest product collection is permitted but where resettlement, transmigration and spontaneous immigration are technically prohibited (Watling \& Mulyana, 1981). The area is primarily occupied by the To Lindu or Kaili Tado, a distinct group of the Kaili people who are indigenous to north-west central Sulawesi (TNC, 2001) and were converted to Christianity during the Dutch conquest in the early 1900s. The area has also witnessed immigration of other Kaili from Kulawi, as well as Bugis people from South Sulawesi, who are attracted to the enclave for cash cropping and participation in the fishing industry at the lake (Acciaioli, 2000).

\section{Methods}

I collected information on human-macaque folklore through semi-structured interviews with villagers of the lakeside village of Tomado from December 2002 to April

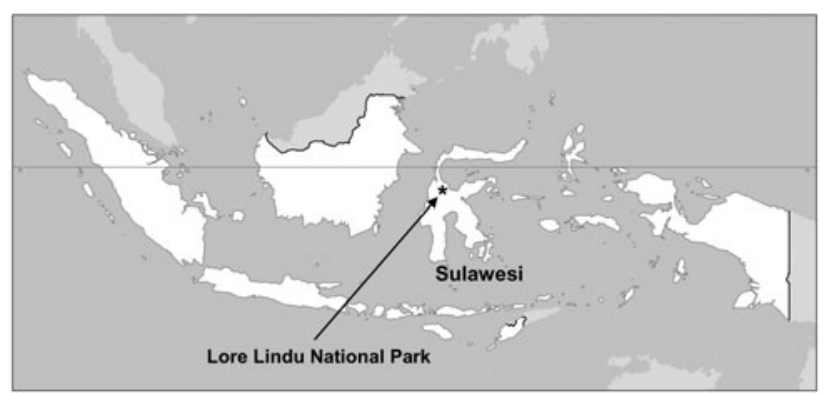

FIG. 1 The location of Lore Lindu National Park on Sulawesi, Indonesia.
2004. Tomado is inhabited by c. 132 households, $90 \%$ of whom are indigenous To Lindu. Respondents, who were selected using a chain-referral approach (Bernard, 1995), were asked to recount folklore regarding the relationship between humans and macaques and human-macaque interactions. The sample of respondents included 26 individuals ( 17 males and nine females): 18 were To Lindu and eight were migrants. I also conducted in-depth interviews with three elders from the neighbouring village of Anca who were identified by others as individuals who knew the details of the folklore. These interviews were taperecorded, with permission, and subsequently transcribed. All interviews were conducted in Bahasa Indonesia (by myself, with the help of an assistant) and later translated into English. Interview data were analysed qualitatively by identifying and describing themes from the respondents' perspectives.

\section{Results}

Of the 26 respondents, $65 \%(n=17)$ knew of humanmacaque folklore but only 15 could recount elements of it. Of the latter, 12 were indigenous Lindu and three were migrants. Three interrelated themes emerged from their responses regarding human-macaque interconnections. The first theme involved perceptions regarding the origin of the macaques, with villagers (both Lindu and migrants) envisioning the monkeys as related to humans. For example:

The story from orang tua [parents/elders] is the people gardening wanted to burn the area but they couldn't get out, so they burned and became monkeys. (Lindu female in her 30s)

Other versions of this belief included:

Two women were collecting esa [grass], a man burned the area with the women, and [they] became monkeys. (Lindu male in his 60s)

There were two women who loved one man. These two women fought in the forest and one of them burned and became a monkey. (Lindu male in his 70s)

Villagers also spoke of the biological similarities between humans and monkeys as evidence of relatedness and kinship. For example:

Monkeys and people are on one line-whereby a human fell into a cooking pot and burned... it lost its butt and its hair turned black. I think it makes sense, we have the same hands. (Migrant male in his 40s)

Monkeys are regarded as kin [by the Lindu]. It is a reciprocal relationship... monkeys will shake a mango tree such that the fruits fall so that we don't have to climb the tree. (Migrant male in his 50s)

The second theme was the nature of human-macaque interactions and how villagers think they should respond to monkeys encountered in the forest or in their gardens (i.e. during crop raiding). For example: 
Don't speak badly to them because then they will be mad. People give them a bit of corn on the outside of the fence and say 'here this is for you' until they don't eat our harvest any more. (Lindu male in his 70s)

If you do something bad to them they will come and disturb us. You leave a few fruits for them and that is all they will take. (Migrant male in his 60s)

None of the respondents from the first set of formal interviews, however, could explain their sentiments. Indepth interviews with three elders (i.e. no person younger than 50 years could recall the story) from the village of Anca revealed a story on a specific human-macaque interaction experienced by a Lindu villager from which the above sentiments likely stem. Below is the full story as told by a Lindu male elder (age 74 years) from the village of Anca:

This story dates back before the arrival of the Dutch. I heard this story when I was still in school because at that time when I came home from school I had to go and guard the gardens.

A man lived with his teenage daughter. One day this man instructed his child to stay at the house because he had to check his fish nets. He told his child that if the monkeys came, to talk harshly with them and say they are not allowed to come here and disturb our crops. What's more is that there were many chicken eggs in the house. At 8.00 or 8.30 in the morning hundreds of monkeys came; they ate maize and squash. The garden was all black because it was full of monkeys. Next, the monkeys began approaching. The young girl began telling them as her father had instructed her to: 'you monkeys are not allowed to bother us or to eat our crops' but the monkeys continued to approach her until they reached the house. They entered the house, and the young girl began beating them with coals from the fire but the monkeys would not leave and then ate all of the chicken eggs. After all the eggs were gone they caught the young girl and left the house for the mountains. There was no one in the village because everyone was at the island Bola for a big adat [customary law] party for three villages. At this time ladang [dry, swidden agriculture] was still practised. The monkeys screamed and made lots of noise because they were happy that they had caught the little girl and then they went to the forest. The hair of the young girl kept getting caught in thorns but the monkeys just kept tugging on her. Her clothes were also caught in thorns and so were covered with holes. The entire time the little girl never fell to the ground because there were so many monkeys. Half of them cried out like humans. They then crossed over seven mountains. Meanwhile, from the lake, the father heard all the noise and commotion so he quickly paddled his way back and went home. He left all the fish, maybe more than 100 that he had caught in the canoe. He went straight to the garden and saw that his child was no longer there. He grabbed his parang [machete] and chased after them over six mountains. As he climbed he couldn't hear them but this was because they were already at the bottom of the seventh mountain. So he descended as well. He climbed a tree and saw his child sitting on top of a flat rock surrounded by seven rows of monkeys. The child was wrapped in traditional mbesa cloth [a highly valued cloth that was originally traded by the Toraja with the To Lindu in exchange for water buffalo] that belonged to the monkeys. He then began to approach the child while the monkeys were singing because they were happy because they got a human gift (the child). From about $4 \mathrm{~m}$ from where the child was sitting, the father leaped and grabbed his child, using the mbesa cloth to carry her. He then pulled out his parang and the monkeys began climbing his body until his skin was torn. But he didn't care because the monkeys were trying to get the child back. He then began using his parang to kill the monkeys until there were two left; one male and one pregnant female and then the father took his child away. He continued to hold onto the parang with all the monkey blood on his hand. From the mountain he bypassed the hut and took the child straight to the island. At the island he held a welcome home celebration for his child by slaughtering a water buffalo. So that's it ... you can't just talk badly to monkeys because according to the story, monkeys are people too.

Others don't want to get angry with the monkeys because they know this story...if we are angry then the monkeys will do something like what happened with the father and his child. Therefore we can't leave behind teenage children or the monkeys will take them.

This story has always been here and will continue to be.

The third theme, which only emerged from To Lindu narratives, pointed to the belief that monkeys act as guardians of Lindu adat:

Monkeys would give a sign if there was a masalah hamil [illegitimate pregnancy; a violation of adat] by destroying the garden and killing dogs and water buffalo. So, we must take one animal, take its blood, take it to the water and deposit it there, so that everything will be all right ... (Lindu male in his 50s)

In the past our ancestors made a mistake. A disrespectful courting resulted in a pregnancy, so the buffalo of people here was caught and attacked by all the monkeys of Anca until the buffalo was dead. According to our ancestors' understanding of it, the spirits in the forest were embarrassed because the masalah hamil was not talked about well but instead the reality was that it was kept quiet. The buffalo was killed by the monkeys as a sign that something bad was committed and that the spirits were angry about it, the land was made filthy... this is the story from our ancestors and almost everybody knows it. The monkeys are really cruel here ... if there has been a problem they will alert us ... gardens will be destroyed. (Lindu female in her 70s)

\section{Discussion}

Human societies have elaborate cultural beliefs, values and customs regarding forests and wildlife, including primates (Sponsel et al., 2002). Research that investigates not only what people do in relation to their environment but also why people do it may inform conservation efforts (Kuriyan, 2002). This was the intention of the research reported here.

The interviews revealed that Lindu villagers possess folklore that envisions monkeys and humans as interrelated biologically, ecologically and culturally. Both the Lindu and the migrants speak of the biological and morphological similarities between macaques and humans, and some even refer to the macaques as kin. It is among the indigenous 
To Lindu, however, that the cultural linkages between macaques and humans are most salient; the macaques are linked to the Lindu via adat. Moreover, the intricate human-monkey kidnapping story was told only by the Lindu. For many Lindu, this story has resulted in a taboo against harming monkeys they encounter in their gardens.

Taboos can be defined as unwritten rules or prohibitions that regulate human behaviour (Saj et al., 2006). Following Colding \& Folke (1997) the Lindu taboo takes the form of a species-specific taboo that appears to be the consequence of both symbolic (i.e. monkeys as humans, monkeys as kin) and mythological (i.e. monkeys as guardians of adat) qualities ascribed to the Tonkean macaque. It is not fear of retribution by supernatural forces (Saj et al., 2006; Jones et al., 2008), however, that determines whether people adhere to the taboo but fear of retribution by the macaques themselves:

If monkeys come to our gardens we can only shoo them away... you can't be harsh because otherwise they will get angry. (Lindu male in his 40s)

Although traditional knowledge and beliefs, such as social taboos, are increasingly being recognized as important to conservation efforts (Colding \& Folke, 2001; Jones et al., 2008), a few caveats regarding a reliance on culture for conservation are warranted. Firstly, any social taboo may be narrow in scope and hence do little to protect overall ecological systems. Saj et al. (2006) found that although a local hunting taboo offers protection to the colobus monkey Colobus vellerosus in the Boabeng-Fiema Monkey Sanctuary in Ghana, such protection does not extend to other wildlife species nor does it result in the protection of surrounding forests. In addition, people's attitudes and beliefs are not culturally fixed points, eternal and unchanging (Knight, 1999; Hill, 2002). For example, at the same Sanctuary, the taboo against hunting colobus monkeys broke down in the 1970 s when Christian missionaries encouraged villagers to hunt as a way to disentangle themselves from the constraints of traditional beliefs (Fargey, 1992; Saj et al., 2006). Among the Iban in Kalimantan, Indonesia, Wadley et al. (1997) found that conversion to Christianity resulted in many people abandoning taboos against the killing and eating of the orangutan Pongo pygmaeus.

A similar pattern has occurred on the Lindu plain. In the past the felling of strangling fig trees (Ficus spp.) was taboo because evil spirits were believed to reside within (Riley, 2005). This taboo has had a conservation outcome because it resulted in the protection of important food sources for many of Sulawesi's fruit-eating birds and mammals (Kinnaird et al., 1999), including the Tonkean macaque (Riley, 2007a). Today, many villagers indicate that the predominance of Christianity now negates the belief in evil spirits. In Lindu, a changing sociocultural environment has therefore resulted in the relaxing of a cultural taboo that may negatively affect the survival of wildlife that depends on fig fruits.

Human-macaque folklore in Lindu, however, appears not to have been affected by the conversion of the To Lindu to Christianity. The inability of younger residents to tell the story may reflect limited transmission of knowledge across generations, as well as changing ecological and socioeconomic conditions in Lindu (i.e. a shift from traditional ladang agriculture to wet-rice agriculture, cash crops and fishing as the major sources of livelihood). Nonetheless, what does remain salient among younger Lindu residents is not so much the details of the story but its essence (i.e. 'If you talk bad to them [monkeys], you will become their enemy'; Lindu male in his $40 \mathrm{O}$ ), a belief that continues to guide people's behaviour as they relate to monkeys, even if they are unaware of the origin of the belief. These remnants of human-macaque folklore and villagers' adherence to the taboo may therefore help to ensure continued protection of the macaques. However, migrants who do not possess such folklore and whose cacao gardens are also raided by macaques may have no qualms about defending their crops. The ability of macaques and humans to coexist at the forest-agriculture ecotone may therefore ultimately require that farmers perceive a utilitarian basis to macaque preservation (Knight, 1999). It is also possible that humanmacaque folklore held by the To Lindu may eventually be abandoned as socioecological and economic conditions continue to change. For example, there are some in Lindu who know the story but who have chosen to disregard it:

He has already heard the story but he is not afraid ... but maybe later there will be a problem. He really doesn't want to do it [make traps] again, after I talked with him. [He] said: 'as opposed to father tiring out having to go there every day, I want to kill them all. I put traps up along the entire maize crop so that each time they enter they will be finished'. I said 'don't you do that'. After I spoke that way he didn't want to do it again. (Lindu female in her 70s, talking about her son's frustration with crop-raiding macaques)

The preservation value of a species may be more meaningful to villagers if they recognize the important roles nonhuman primates play in forest ecosystem dynamics. For example, the documentation of primate seed dispersal of tree species that have economic and/or cultural value for villagers may provide a strong argument for the protection of primate populations (Lambert, 1998) that bridges both Western conservation values and local values. In Lindu, if Tonkean macaques are major seed dispersers for forest resources that are highly valued by villagers (e.g. Elmerillia ovalis, Elmerillia tsiampaccca and Arenga pinnata; Riley, 2007b), both indigenous Lindu and migrants, the preservation of macaques may become important for the community as a whole.

'True conservation' has been defined by Smith \& Wishnie (2000:501) as 'actions or practices that (a) prevent or mitigate 
resource depletion, species extirpation, or habitat degradation, and (b) [are] designed to do so'. Although the findings from Lindu do not necessarily fit the latter part of this definition, the persistence of human-macaque folklore and the behavioural patterns that result from it may ultimately have a conservation outcome if the taboo against harming the macaques continues to protect them in areas of humanmacaque overlap. This research therefore exemplifies the important role informal institutions, such as social taboos, can play in conservation, particularly in linking the interests and concerns of local human communities and conservation managers, who tend to promote intrinsic conservation ethics; Colding \& Folke, 2001). At the same time, because local environmental values are often 'multifaceted and differential' (Ellen, 1993:139), as demonstrated here, conservation practitioners may still need to work towards a convergence of values (Weber, 1987). My research also suggests that social taboos may be particularly important for primate conservation in special use areas of UNESCO national parks where various forms of small-scale resource use and extraction are allowed. Long-term conservation success in such protected areas requires concerted efforts to balance the requirements of humans and other primates in their shared environments.

\section{Acknowledgements}

The Indonesian Institute of Sciences and the Indonesian Ministry of Forestry (PHKA) granted permission to conduct the research and Dr Noviar Andayani provided sponsorship. Funding was provided by the Wenner-Gren Foundation, the National Science Foundation, Wildlife Conservation Society and American Society of Primatologists. I thank Carolyn Ehardt and two reviewers for their helpful comments on earlier drafts. My field assistants Manto, James, Papa Denis, Pak Asdi, Pias, Tinus and Papa Tri deserve special thanks and recognition.

\section{References}

Acciaioli, G.L. (2000) Kinship and debt: the social organization of Bugis migration and fish marketing at Lake Lindu, Central Sulawesi. Bijdragen tot de Taal-, Land- en Volkenkunde, 156, 589617 .

Achard, F., Eva, H.D., Stibig, H., Mayaux, P., Gallego, J., Rochards, T. \& Malingreau, J. (2002) Determination of deforestation rates of the world's humid tropical forests. Science, 297, 999-1002.

Bernard, H.R. (1995) Research Methods in Anthropology: Qualitative and Quantitative Approaches. Altamira Press, Lanham, USA.

Brandon, K.E. \& Wells, M. (1992) Planning for people and parks: design dilemmas. World Development, 20, 557-570.

Brechin, S.R., Wilshusen, P.R., Fortwangler, C.L. \& West, P.C. (eds) (2003) Contested Nature: Promoting Biodiversity with Social Justice in the Twenty-First Century. State University of New York Press, Albany, USA.
Chapple, C.K. (1993) Nonviolence to Animals, Earth, and Self in Asian Tradition. State University of New York Press, Albany, USA.

Colding, J. \& Folke, C. (1997) The relations among threatened species, their protection, and taboos. Ecology and Society, 1, 1-13.

Colding, J. \& Folke, C. (2001) Social taboos: 'invisible' systems of local resource management and biological conservation. Ecological Applications, 11, 584-600.

Cormier, L.A. (2003) Kinship with Monkeys: The Guaja Foragers of Eastern Amazonia. Columbia University Press, New York, USA.

Eudey, A.A. (1994) Temple and pet primates in Thailand. Revue d'Ecologie (La Terre et la Vie), 49, 273-280.

Fargey, P.J. (1992) Boabeng-Fiema Monkey Sanctuary: an example of traditional conservation in Ghana. Oryx, 26, 151-156.

Fuentes, A. \& Wolfe, L. (eds) (2002) Primates Face to Face: The Conservation Implications of Human-Nonhuman Primate Interconnections. Cambridge University Press, New York, USA.

Hill, C.M. (2002) Primate conservation and local communities: ethical issues and debates. American Anthropologist, 104, 1184-1194.

IUCN (2009) 2009 IUCN Red List of Threatened Species v. 2009.2. Http://www.iucnredlist.org [accessed 26 January 2010].

Jones, J.P.G., Andriamarovololona, M.M. \& Hockley, N. (2008) The importance of taboos and social norms to conservation in Madagascar. Conservation Biology, 22, 976-986.

Kinnaird, M.F., O’Brien, T.G. \& Suryadi, S. (1999) The importance of figs to Sulawesi's imperiled wildlife. Tropical Biodiversity, 6, 5-18.

Knight, J. (1999) Monkeys on the move: the natural symbolism of people-macaque conflict. Journal of Asian Studies, 58, 622-647.

Коттак, C.P. \& Costa, A.C.G. (1993) Ecological awareness, environmentalist action, and international conservation strategy. Human Organization, 52, 335-343.

KURIYAN, R. (2002) Linking local perceptions of elephants and conservation: Samburu pastoralists in northern Kenya. Society and Natural Resources, 15, 949-957.

Lambert, J.E. (1998) Primate frugivory in Kibale National Park, Uganda, and its implications for human use of forest resources. African Journal of Ecology, 36, 234-240.

Lee, T.M., Sodht, N.T. \& Prawiradilaga, D.M. (2007) The importance of protected areas for the forest and endemic avifauna of Sulawesi (Indonesia). Ecological Applications, 17, 1727-1741.

Lowe, C. (2004) Making the monkey: how the Togean macaque went from "new form" to 'endemic species' in Indonesians' conservation biology. Cultural Anthropology, 19, 491-516.

Mascia, M.B., Brosius, J.P., Dobson, T.A., Forbes, B.C., Horowitz, L., McKean, M.A. \& Turner, N.J. (2003) Conservation and the social sciences. Conservation Biology, 17, 649-650.

Medin, D.L. \& Atran, S. (eds) (1999) Folkbiology. MIT Press, Cambridge, USA.

Orlove, B.S. \& Brush, S.B. (1996) Anthropology and the conservation of biodiversity. Annual Review of Anthropology, 25, 329-352.

RiLey, E.P. (2005) Ethnoprimatology of Macaca tonkeana: the interface of primate ecology, human ecology, and conservation in Lore Lindu National Park, Sulawesi, Indonesia. PhD thesis, University of Georgia, Athens, USA.

RILEY, E.P. (2007a) Flexibility in diet and activity patterns of Macaca tonkeana in response to anthropogenic habitat alteration. International Journal of Primatology, 28, 107-133.

RILEY, E.P. (2007b) The human-macaque interface: conservation implications of current and future overlap and conflict in Lore Lindu National Park, Sulawesi, Indonesia. American Anthropologist, 109, 473-484.

Saj, T.L., Mather, C. \& Sicotte, P. (2006) Traditional taboos in biological conservation: the case of Colobus vellerosus at the 
Boabeng-Fiema Monkey Sanctuary, Central Ghana. Social Science Information, 45, 285-310.

Shepard, G.H. (2002) Primates in Matsigenka subsistence and world view. In Primates Face to Face: Conservation Implications of Human-Nonhuman Interconnections (eds A. Fuentes \& L. Wolfe), pp. 101-136. Cambridge University Press, New York, USA.

Smith, E.A. \& Wishnie, M. (2000) Conservation and subsistence in small-scale societies. Annual Review of Anthropology, 29, 493-524.

SPONSEL, L.E. (1997) The human niche in Amazonia: explorations in ethnoprimatology. In New World Primates: Ecology, Evolution, and Behavior (ed. W.G. Kinnzey), pp. 143-165. Aldine Gruyter, New York, USA.

Sponsel, L.E., Ruttanadakul, N. \& Natadecha-Sponsel, P. (2002) Monkey business? The conservation implications of macaque ethnoprimatology in southern Thailand. In Primates Face to Face: Conservation Implications of Human-Nonhuman Interconnections (eds A. Fuentes \& L. Wolfe), pp. 288-309. Cambridge University Press, New York, USA.

TNC (The Nature Conservancy) (2001) Lore Lindu National Park: A Visitor's Guide. Sulawesi Parks and Partnership Program. Directorate General of Forest Protection and Nature Conservation, The Nature Conservancy, Jakarta, Indonesia, Directorate General of Forest Protection and Nature Conservation, Jakarta, Indonesia, and USAID, Jakarta, Indonesia.

Wadley, R.L., Colfer, C.J.P. \& Hood, I.G. (1997) Hunting primates and managing forests: the case of Iban forest farmers in Indonesian Borneo. Human Ecology, 25, 243-271.

Watling, D. \& Mulyana, Y. (1981) Lore Lindu National Park Management Plan 1981-1986. A Report for the Directorate of Nature Conservation, Bogor, Indonesia.
Weber, A.W. (1987) Socioecologic factors in the conservation of Afromontane forest reserves. In Primate Conservation in the Tropical Rain Forest (eds C.W. Marsh \& R.A. Mittermeier), pp. 205-229. Alan R. Liss, New York, USA.

Wells, M.P. \& MCShane, T.O. (2004) Integrating protected area management with local needs and aspirations. Ambio, 33, 513-519.

West, P.C., Igoe, J. \& Brockington, D. (2006) Parks and people: the social impact of protected areas. Annual Review of Anthropology, 35, 251-277.

Wheatley, B.P. \& Harya Putra, D.K. (1995) Hanuman, The Monkey God, leads conservation efforts in the Balinese monkey forest at Ubud, Indonesia. Primate Report, 41, 55-64.

Zhно, Q.K. (2005) Tibetan macaques, visitors, and local people at Mt. Emei: problems and countermeasures. In Commensalism and Conflict: The Human-Primate Interface (eds J. Paterson \& J. Wallis), pp. 376-399. American Society of Primatologists, Norman, USA.

\section{Biographical sketch}

ERIN P. RILEY's research interests combine primate socioecology, conservation biology and environmental anthropology. She has conducted field research on the Sulawesi macaques of Indonesia for the past 10 years. She also is part of a new collaborative project (with the Zoological Society of San Diego's Institute for Conservation Research) studying the behaviour, ecology and conservation of the Guizhou snub-nosed monkey Rhinopithecus brelichi in Fanjingshan Nature Reserve, China. 